\title{
BAD DEBT DEDUCTIONS FOR CAPITAL LOST THROUGH BREACH OF CONTRACT *
}

By allowing deduction for bad debts, section 166 of the Internal Revenue Code compensates creditors for taxes paid on lost capital. Encompassing losses from debts which become worthless during the taxable year, ${ }^{1}$ the section effects a return of the tax presumably levied when the capital was earned. ${ }^{2}$ Accord-

*United States v. Kyle, 242 F.2d 825 (4th Cir. 1957).

1. INT. Rev. CoDE of 1954, $\$ 166$ (a) (1). Alternatively, a deduction may be taken for a reasonable addition to a reserve for bad debts. Id. $\$ 166(\mathrm{c})$. See, generally, 5 Merrens, Federar Income Taxation $\S 30$ (1956) (hereinafter cited as Mertens) ; Propp, what To Do About Bad Debts, N.Y.U. 13rH Inst. on FED. TAX. 109 (1955) ; Grundwerg, Nonbusiness Bad Debts-Is the Taxpayer Getting the Business?, 8 Mianr L.Q. 593 (1954); Justis, Is It a Debt? Is It a Bad Debt? Is It a Business Bad Debt?, N.Y.U. 10тH Inst. on Fed. TAX. 183 (1952); Danzig, Bad Debts and What the Individual Can Do About Them, N.Y.U. 9TH Inst. on FED. TAx. 393 (1951); Guterman, Some Problens in the Deduction for Bad Debts, 63 HARv. L. REv. 332 (1950) ; Hanigsberg, Distinguishing a Fully Deductible Loss From a Non-Business Bad Debt, N.Y.U. 7TH INST. ON FEd. TAX. 914 (1949) ; Tye, Pointers in Bad Debts, Worthless Securities and Other Business Losses, N.Y.U. 6TH INsT. on Fed. TaX. 681 (1948) ; Green, Outline of Points To Be Considered in Bad Debt and Worthless Security Write-offs, N.Y.U. 5TH INST. on Fed. TAX. 646 (1947).

The prerequisites of deductibility are: a valid and enforceable debt, George J. Schaefer, 24 T.C. 638 (1955), rev'd on other grounds, 240 F.2d 381 (2d Cir. 1957), owed to the taxpayer, Kentucky Rock Asphalt Co. v. Helburn, 108 F.2d 779 (6th Cir. 1940), which had value when acquired, Miriam C. Pierson, 27 T.C. 330 (1956); Eckert v. Burnet, 283 U.S. 140 (1931), is determined to be worthless within the taxable year, Lockwood Myrick, P-H 1956 T.C. Mem. Dec. If 56010, and in which the taxpayer has a basis, 5 MERTENS $\$ 30.12$; see note 3 infra. See also Proposed U.S. Treas. Reg. $\$ \$ 1.166-7$ (a), (c) (1956). A debt has been defined as "that which is due from one person to another, whether money, goods or services; that which one person is bound to pay to another, or to perform for his benefit .... [that which is an] unconditional obligation to pay." Gilman v. Commissioner, 53 F.2d 47, 50 (8th Cir. 1931), quoted in David E. Thompson, P-H 1944 T.C. Mem. Dec. $\Uparrow 44175$. It has also been defined as "every claim and demand upon which a judgment for a sum of money, or directing the payment of money, could be recovered in an action." Ambrose D. Henry, 8 B.T.A. 1089, 1097 (1927). The basic test is the existence of an unconditional obligation to pay, Thompson v. Commissioner, 235 F.2d 599 (9th Cir. 1956) ; 5 MERTENS $\$ 30.03$, or of a debtor-creditor relationship, Henry v. Burnet, 48 F.2d 459 (D.C. Cir. 1931) ; Birdsboro Steel Foundry \& Mach. Co. v. United States, $78 \mathrm{Ct}$. Cl. 100, 3 F. Supp. 640 (1933). See also Proposed U.S. Treas. Reg. $\S 1.166-1(f)$ (1956). Accordingly, the historical distinction between actions of indebitatus and speeial assumpsit, see 5 Corbin, Contracts $\S 995$ (1951) (hereinafter cited as CoRBIN), is not relevant in this area of tax law, since debts arising from either may satisfy the criteria of deductibility. But see 3 RIA, FED. TAX CoORdinATOR \$ M-2501, at nn.3-6 and accompanying test, attempting to distinguish a debt from breach of contract and relying on Lewellyn v. Electric Reduction Co., 275 U.S. 243 (1927), shown inapposite, note 16 infra.

2. A deduction from current income may not return the exact tax previously paid since the income tax assessment, measured by a percentage of taxable income, varies with the taxpayer's "bracket" in a given year. See INT. Rev. Code of 1954, §§ 1, 3. If a tax- 
ingly, a debt is deductible only to the extent the taxpayer fails to realize a return of capital. ${ }^{3}$ Full deductibility from ordinary income, however, is denied even that portion of a nonbusiness bad debt which represents unreturned capital. ${ }^{4}$ Since many nonbusiness loans are in fact gifts, the Code, in a blanket attempt to increase revenue and avoid inordinate problems of detection and enforcement, treats nonbusiness bad debts as deductible short-term capital losses. ${ }^{5}$ Nonbusiness capital losses reflecting either depreciation or market

payer's adjusted gross income at the time the capital was earned were less than the deductions to which he was entitled, a subsequent bad debt deduction would yield a net tax gain, for the taxpayer would not have paid a tax on the income when received. Cf., e.g., Maurice P. O'Meara, \& T.C. 622 (1947). Similarly, exempt income or gift or bequest may be the source of the taxpayer's capital. See, generally, 1 Mertens $\$ 5.06$, at n.48. In the former instance, however, a bad debt deduction may represent compensation for a lost tax advantage. To the extent inclusion of the income subsequently lost offsets a deduction which could have been utilized in another taxable year, the taxpayer suffered a disadvantage. Cf., c.g., Note, 65 Y ALE L.J. 1045 (1956). However, since the year in which money subsequently lost in a bad debt was earned is impossible to determine, a deduction from current income is the only feasible method of compensating the average taxpayer for his previous tax payment.

The bad debt deduction may not have originally been rationalized in economic terms. It may have derived from a nonrational, sympathetic reaction favoring disappointed creditors and encouraging the extension of credit or a desire to accord bad debts a treatment comparable to that given other investment losses. Cf. note 6 infra. Theoretically, a bad debt deduction, based upon economic considerations, should be geared to the length of time the taxpayer had the beneficial use of the lost capital. Obviously, this theory is impossible to effectuate since taxpayers as a rule do not segregate annual income.

3. "[T] $T$ he basis for determining the amount of the deduction for any bad debt shall be the adjusted basis provided in section 1011 for determining the loss from the sale or other disposition of property." INT. REv. CODE of 1954, § 166(b). The adjusted cost basis represents the after-tax income invested by the taxpayer in the particular capital asset. See id. $\$ \S 1011,1012,1016$.

A bad debt deduction will not be allowed for failure to receive funds which have never been reported as income. Henry V. Poor, 11 B.T.A. 781 (1928), aff'd per curiam, 30 F.2d 1019 (2d Cir. 1929) ; John L. Seymour, 14 T.C. 1111 (1950) (bonus stock); Maurice P. O'Meara, supra note 2, at 633 (royalties); Charles A. Collin, 1 B.T.A. 305 (1925) (interest); Proposed U.S. Treas. Reg. $\$ 1.166-2$ (1956) (uncollectible obligations to pay income items such as wages and salaries, rents and interest). Similarly, deduction has been denied for failure to receive funds which were not taxable income where taxpayer had no basis which would establish a loss. W. Thomas Menefee, 8 T.C. 309 (1947) (alimony); Pearl A. Long, 35 B.T.A. 479 (1937), aff'd on other gronnds, 96 F.2d 270 (9th Cir. 1938) (same).

4. Business bad debts, on the other hand, are fully deductible from income, INr. Rev. CODE of 1954, § 166(a) (1), to the extent that they are worthle'ss, id. \$166(a) (2). Unused deductions may be applied as net operating carrybacks and carryovers without the limitations applicable to capital losses. Compare id. $\$ 172$ (net operating loss carryover), with id. $\S 1212$ (capital loss carryover). All bad debts owed a corporation are business bad debts. Id. $\$ 166$ (d) (1).

5. Int. REv. CoDE of 1954, $\S 166$ (d) (1) (B). Consequently, nonbusiness bad debts are deductible from capital gains and taxable income up to $\$ 1,000$ under $\$ 1211$ (b). A fiveyear carryover provision applies. Id. $\$ 1212$. Partial deduction of nonbusiness bad debts is not permitted. Id. $\$ 166$ (d) (1) (A) ; Proposed U.S. Treas. Reg. $\$ 1.166-7$ (a) (1956). 
fluctuations, on the other hand, are not granted a deduction. ${ }^{6}$ Often, bad debts manifest characteristics typical of such nondeductible losses. ${ }^{7}$ In this event, attention focused on irrelevant aspects of a transaction may give rise to inequitable tax treatment.

In the recent case of United States $v$. Kyle, for example, an uncollectible judgment for breach of contract was treated as a nondeductible capital loss. ${ }^{8}$

This reduced tax benefit diminishes incentive to defraud the government, increases total revenue and permits the Commissioner to forego litigation without significant revenue loss. Note, 65 Y ALE L.J. $247 \mathrm{n.4}$ (1955). For the legislative background and success of the 1942 act, Int. Rev. Code of 1939, $\$ 23(\mathrm{k})(4)$, added by 56 STAт. 821 (1942) (now INT. REv. CODE OF 1954, § 166(d)), which first distinguished between business and nonbusiness bad debts, see Note, 65 YaLE L.J. 247 n.4 (1955). See, generally, Guterman, supra note 1 .

In Putnam v. Commissioner, 352 U.S. 82 (1956), the Supreme Court divided on the purpose of the business-nonbusiness bad debt distinction. The majority argued a dual policy: maximization of revenue to finance World War II with a correlative minimization of fraudulent deductions for gifts disguised as loans, and an attempt to "put nonbusiness investments in the form of loans on a footing with other nonbusiness investments." Id. at 90-92. The dissent contended that the congressional objective was solely to reduce revenue losses on gifts deducted as bad debts. Id. at 98-99.

However, the distinction impedes full deduction of losses on nonbusiness transactions entered into for profit which happen to involve default on an obligation. See Note, 65 YALE L.J. 247 (1955) (criticizing this result). For the differences between bad debts and losses generally, see 5 MERTENS $\$ 30.14$.

An alternative means of preventing fraudulent deduction of gifts disguised as loans would be a provision patterned after INT. REv. CODE of 1954, § 267, which prevents deductions for losses on intrafamily transactions. Since the $\S 166$ business-nonbusiness distinction was aimed primarily at loans between related taxpayers, see H.R. REP. No. 2333, 77th Cong., 2d Sess. 45 (1942), such a provision would implement the original intent. Furthermore, the problem of proof facing the Commissioner, which the 1942 act sought to relieve, could be met by stringent enforcement of the requirement that a taxpayer show the existence of a valid and enforceable legal obligation which had value when acquired and which later became worthless. See 5 MERTENs $\$ \$ 30.03,30.11,30.28$; note 1 supra.

6. INT. REv. CODE of 1954, §165(c), allows individuals to deduct only those losses incurred in a trade or business, in a transaction entered into for profit or through casualty or theft. For purposes of deductibility, bad debts and capital losses are mutually exclusive categories. Spring City Foundry Co. v. Commissioner, 292 U.S. 182 (1934); 5 MERTENs $\S 30.14$. Furthermore, the statute of limitations for claims of credit or refund is seven years for bad debts and only three years for ordinary losses. Compare INT. REv. CODE OF 1954, § 6511 (d) (1), with id. § 6511(a).

Section 262 provides that, absent specific exceptions, "no deduction shall be allowed for personal, living, or family expenses." Generally, a decrease in value of nonbusiness property reflects depreciation from use. Thus, the diminution is due to value received by the taxpayer, a nondeductible cost of living. Since the loss cannot be apportioned between depreciation and market fluctuations, and since the market presumably will reflect the general cost of living, no attempt is made to permit a deduction when the loss is out of proportion to value received.

7. Nonbusiness contract losses mitigated by sale on the market, failure to recover anticipated damages for injury to property and unreimbursed satisfaction of contractual obligations, guaranties or suretyships are examples of transactions which may resemble both nondeductible losses and bad debts.

8. 242 F.2d 825 (4th Cir. 1957), reversing 142 F. Supp. 786 (E.D. Va. 1956). 
Taxpayer contracted to sell his house and received partial payment on December $2 .^{\circ}$ The balance was to be paid and the title pass on December 30 . Taking possession on December 15, the purchaser refused to remit the balance when due. ${ }^{10}$ Six months later, he surrendered possession, and taxpayer sold the house for less than contract price and basis..11 Taxpayer was subsequently awarded a judgment for the difference between contract and market price. ${ }^{12}$ Since the judgment proved uncollectible, he sought to deduct as a bad debt that portion which represented the difference between basis and recovery in mitigation-his unreturned capital. ${ }^{13}$ Because title had not passed, the court considered the contract executory and therefore disregarded the default and judgment ${ }^{14}$ holding the transaction a loss on the sale of a personal residence, it denied the deduction. ${ }^{15}$

9. The contract of sale set a purchase price of $\$ 17,750$, and a down payment of $\$ 700$ was made. $I d$. at 826 .

10. Ibid. The opinions do not reveal whether this refusal constituted an immediate total breach, attempted recision or merely failure to tender the purchase money. However, no immediate duty to mitigate was created in the vendor since the vendee did not surrender occupancy for six months, see note 11 infra and accompanying text, and the vendor's damages were measured by contract price less market value at the time of the stipulated sale six months later, see note 12 infra and accompanying text.

11. 242 F.2d at 826 . Taxpayer's basis in the residence was $\$ 16,500$, the price paid for the house less than three months earlier. Kyle v. United States, 142 F. Supp. 786 (E.D. Va. 1956). The vendee surrendered possession June 19, 1947. Taxpayer recovered $\$ 13,500$ on the market in a stipulated sale, June 27, 1947. $242 \mathrm{~F} .2 \mathrm{~d}$ at 826 . Whether the house was actually sold on the market as the state report implies, Henning v. Kyle, 190 Va. 247, 250, 56 S.E.2d 67, 68 (1949), or whether a sale was stipulated for the purpose of measuring the contract damages as the federal reports suggest, 242 F.2d at 826; Kyle v. United States, 142 F. Supp. 786 (E.D. Va. 1956), is unclear. The state report indicates that taxpayer initially brought a price action and amended his complaint to sue for the difference between contract and market price. In any event, the sale price was $\$ 4,250$ less than contract price and $\$ 3,000$ less than taxpayer's basis.

12. Henning v. Kyle, 190 Va. 247, 56 S.E.2d 67 (1949) ; 242 F.2d at 826. Taxpayer recovered a judgment for $\$ 4,415$. Henning v. Kyle, 190 Va. 247, 249, 56 S.E.2d 67,68 (1949). This represented lost profits of $\$ 1,250$ (contract price of $\$ 17,750$ less $\$ 16,500$ basis), $\$ 2,300$ net loss on the sale in mitigation $(\$ 16,500$ basis less the $\$ 13,500$ market recovery less the $\$ 700$ deposit) and interest of $\$ 865$. Brief for Appellants, p. 6 , United States v. Kyle, 242 F.2d 825 (4th Cir. 1957).

13. $242 \mathrm{~F} .2 \mathrm{~d}$ at 826 . The taxpayer in Kyle claimed the deduction under Int. Rev. Code of 1939, § 23(k) (4), added by 56 Stat. 821 (1942) (now Int. Rev. Code of 1954, § 166(d)). The federal district court ruled in his favor. Kyle v. United States, 142 F. Supp. 786 (E.D. Va. 1956). See note 18 infra.

During the argument before the Fourth Circuit, the parties agreed that the portion of the judgment representing interest and the difference between basis and contract price was not deductible. Therefore, the amount in controversy was $\$ 2,300(\$ 3,000$ difference hetween market value and contract price minus the $\$ 700$ down payment). $242 \mathrm{~F} .2 \mathrm{~d}$ at 826 . Invoking the five-year capital loss carryover provision, Int. Rev. Code of 1939, $\$ 117$ (e) (1), added by 56 STAт. 844 (1942) (now Int. REv. CoDE of 1954, § 1212), the taxpayer claimed a deduction against income for the years 1949-52. 242 F.2d at 826 .

14. $I d$. at 825 .

15. Id. at 828. The court distinguished cases cited by taxpayer because "the losses which were allowed as bad debts did not exceed the adjusted cost bases of the properties 
The distinction in Kyle between executory and unilaterally performed contracts, while consistent with prior case law, seems an unrealistic ground for determining deductibility. ${ }^{16}$ Traditionally, a purchase money mortgagee, who

involved." Id. at 826 . However, the taxpayer in Kyle gave up his claim for nonrecovery of the contract price to the extent that it exceeded basis. The amount he sought to deduct on appeal was the difference between basis and the amount he recovered on the market through enforcing his vendor's lien. See note 13 supra; cf. Brief for Appellees, pp. 6-8, United States v. Kyle, 242 F.2d 825 (4th Cir. 1957).

The opinion dealt with the suggestion that the deduction might be allowed as a loss on "any transaction entered into for profit, though not connected with a trade or business," under $\$ 23$ (e) of the 1939 Code, 53 Stat. 13 (now INT. Rev. Code of 1954, \$ 165(c) (2)). $242 \mathrm{~F} .2 \mathrm{~d}$ at $825-28$. Inasmuch as taxpayer purchased the house less than three months prior to the profitable contract of sale, accepted a downpayment and permitted the vendee to occupy, and sustained a loss, he had at least an apparent claim under $\$ 23(\mathrm{e})$. The court held to the contrary on the ground that the property had not been "appropriated to income producing purposes" within the meaning of U.S. Treas. Reg. 1.11, $\$ 29.23$ (e)-1 (1943) (now Proposed U.S. Treas. Reg. \$ 1.165-3(b) (1956)). 242 F.2d at \$27. But this regulation contemplates purchase and use of the house as a personal residence, and no indication of this situation was given in $K y l e$. Moreover, loss on the sale of property acquired with the predominant purpose of selling at a profit may be deducted even though the taxpayer used the property as his personal residence. 5 Mertens $\$ 28.78$. Not recognizing these possibilities, the court's interpretation unnecessarily constricts application of $\S 165$. Still, the opinion may be justified in that the existence of a distinction between $\$ 165$ losses and $\$ 166$ bad debts militates in favor of denying the deduction under $\$ 165$ and ruling that the taxpayer suffered a bad debt. See notes 34-37 infra and accompanying text.

16. Except in instances where the taxpayer has previously accrued and paid a tax on income to be realized, see, e.g., Leedom \& Worrall Co., 10 B.T.A. 825 (1928), no case has allowed a deduction to a liquidated claim for breach of an executory contract. See Justis, supra note 1, at 192. See also David E. Thompson, P-H 1944 T.C. Mem. Dec. I 44175 (dictum distinguishing between an executory contract and a contract of sale). But sec Farmer's Elevator \& Exchange, 10 B.T.A. 379 (1928) ; Bert K. Smith, 5 B.T.A. 480 (1926). However, the reports of these latter cases are inadequate, see 3 PAUL \& MERTENs, Federal Incone Taxation $\S 28.13$, at $n .45$ (1934), and the claims may have been previously reported as income since they were so written up on the taxpayers' books.

For cases allowing bad debt deductions for claims for breach of executed contracts, set Charles B. Bohn, 43 B.T.A. 953 (1941) ; Mary E. Wenger, 42 B.T.A. 225 (1940) ; James R. Stewart, 39 B.T.A. 87 (1939) ; Fort Pitt Bridge Works, P-H 1942 B.T.A. Mem. Dec. I 42078; W. Van E. Thompson, 10 B.T.A. 1125 (1928). An executed contract resembles the simple loan situation. See, e.g., Robert W. DePuy, 14 CCH Tax Ct. Mem. 268 (1955); Meurer Steel Barrel Co., 7 B.T.A. 64 (1927).

Cases denying bad debt deductions to claims for breach of executed contracts turn on the unliquidated status of the claims. See, e.g., National Contracting Co. v. Commissioner, 105 F.2d 488 (8th Cir. 1939); Wadsworth Mfg. Co. v. Commissioner, 44 F.2d 762 (6th Cir. 1930) (amount of liability not fixed in year for which a deduction sought). Compare Fort Pitt Bridge Works, supra. Reduction of a claim to judgment is only one means of liquidating a debt and a return of execution unsatisfied only one method of revealing its worthlessness. See Norwood Morris Plan Co. v. McCarthy, 295 Mass. 597, 4 N.E.2d 450 (1936) ; 5 MERTENS $\$ \$ 30.28,30.40$.

The courts have been unwilling to allow a deduction for a worthless claim for hreach of contract absent sufficient performance by the taxpayer to furnish a basis for the amount of the bad debt deduction. Green, supra note 1 , at 647 ; note 3 supra. So in $K y l c$, the Fourth Circuit required performance despite liquidation of the claim by judgment, in the 
executes a sale by conveying title, has been allowed a bad debt deduction for unreturned capital reflected in a worthless mortgage debt. ${ }^{17}$ The taxpayer in Kyle is in the same practical position as the mortgagee. ${ }^{18}$ Upon default by the

mistaken belief that a deductible debt could not exist without an outlay of cash or property to the debtor. 242 F.2d at 827 .

Authorities quoting the rule that a bad debt deduction will not be allowed for claims for breach of contract, even when reduced to judgment, rely primarily on Lewellyn v. Electric Reduction Co., 275 U.S. 243 (1927), 12 MrNs. L. REv. 417 (1928). See, e.g., Hanigsberg, supra note 1, at 916-17 nn.8-10; Green, supra note 1, at 648 n.10; Tye, supra note 1 , at $682 \mathrm{n} .12$. There, the taxpayer paid in advance for merchandise which was never received. He reduced his claim for refund of the purchase price to judgments in 1919 and 1922 and sought to adjust his 1918 return for the uncollectible debt. The deduction was disallowed. The Court said that "the buyer's rights were upon a contract for the delivery of merchandise and were not a 'debt' in either a technical or a colloquial sense." Lewellyn v. Electric Reduction Co., supra at 246. However, since the judgment postdated the year for which deduction was claimed, since the debt was in no way liquidated in that year, and since taxpayer apparently did not abandon his rights on the contract in that year, Lezicllyu does not preclude holding uncollectible liquidated claims for breach of executory contracts deductible as bad debts. See 3 Paul \& Mertens, Federal Income Taxation \$28.13 (1934) ; 3 RIA, Fed. TAx Coordrnator \$ M-1101, at n.19; Justis, supra note 1. Instead, it merely holds that a contested claim is not a debt. See Birdsboro Steel Foundry \& Machine Co. v. United States, 78 Ct. C1. 100, 3 F. Supp. 640 (1933).

17. See, e.g., Harold S. Denniston, 37 B.T.A. 834 (1938) (bad debt deduction allowed for difference-constituting unreturned capital-between purchase money mortgage debt released and HOLC bonds received); Doris D. Havemeyer, 45 B.T.A. 329 (1941). And see Proposed U.S. Treas. Reg. $\$ 1.166-3$ (1956) :

"(a) If mortgaged or pledged property is lawfully sold (whether to the creditor or another purchaser) for less than the amount of the debt, and the portion of the indebtedness remaining unsatisfied after such sale is wholly or partially uncollectible, the mortgagee or pledgee may deduct such amount (to the extent that it constitutes capital or represents an item the income from which has been returned by him) as a bad debt for the taxable year...."

If a mortgagee purchases the property at the foreclosure sale for more than market value, he is allowed a bad debt deduction for the difference between the amount of the debtor's obligations applied to the purchase or bid price of the property and the full value of the debt ("to the extent that it constitutes capital or represents an item the income from which has been returned by him"), and a capital loss deduction for the difference between the amount paid and fair market value. If he purchases for less than the fair market value, he realizes capital gain in addition to the bad debt deduction. However, absent clear proof to the contrary, the amount bid by the taxpayer is presumed to equal fair market value. In this event, the mortgagee, of course, has only the bad debt deduction. Proposed U.S. Treas. Reg. \& 1.166-3 (1956).

Whatever economic gain the mortgagee realizes from purchasing for less than market value is subject to the mortgagor's ability to recoup the property at the deflated bid price in states where a redemption period is applicable. Green, supra note 1 , at 653 .

18. See Osrorne, Mortgages $\$ \$ 20,95,213$, at 554-55 \& n.15 (1951) (hereinafter cited as Osrorne); 1 Glenn, Mortgages $\$ \S 15,15.1$ (1943) (hereinafter cited as GLenN). See also Lewis v. Hawkins, 90 U.S. (23 Wall.) 119 (1874) ; James R. Stewart, 39 B.T.A. 87, 90 (1939). Taxpayer's judgment for breach of contract in Kyle-measured by the difference between contract and market price-is comparable to a mortgagee's deficiency judgment measured by the difference between contract price and either foreclosure sale price 
buyer, the mortgagee must sue to eject, foreclose and obtain a deficiency judgment to regain his presale position. ${ }^{19}$ Similarly, the seller who has surrendered possession but not title must sue in ejectment and for damages to avoid loss on his bargain. ${ }^{20}$ In many states, moreover, the mortgagee has certain rights as record holder, and in so far as he possesses title, his legal position parallels that

or "fair value." Cf. OsRoRNe $\S 333,335$. The district court had analogized the judgment representing the unpaid balance of the purchase price to a note or other form of security and pointed out that uncollectible notes given for the purchase price in the sale of realty are deductible when worthless. Kyle v. United States, 142 F. Supp. 786-87 (E.D. Va. 1956); see W. Van E. Thompson, 10 B.T.A. 1125 (1928). See also Charles B. Bohn, 43 B.T.A. 953 (1941) ; Mary E. Wenger, 42 B.T.A. 225, $232-33$ (1940) ; James R. Stewart, supra. While the circuit court admitted that the purchaser had acquired an "equitable interest" in the property, it regarded nonpassage of title as determinative for tax purposes. See 242 F.2d at 825 , 827. But title is pragmatically irrelevant to the nonrevenue rights and remedies of the parties. See WALSH, EQUITY $\S 59$ (1930) (hereinafter cited as WAISH). For the extent of the similarities, see notes $20-21$. infra and accompanying text. C.f. also Proposed U.S. Treas. Reg. $\$ 1.165-1$ (a) (2) (1956) (formerly U.S. Treas. Reg. $111, \S 29.23$ (e)-1 (1943)) ("substance and not mere form will govern in determining deductible losses").

Unlike a cash basis taxpayer, an accrual basis seller is taxed on the gain realized by a contract of sale when the purchaser becomes unconditionally obligated to pay for the property. This liability may occur before delivery of the deed, and hence title, if the buyer takes possession under a contract which requires the taxpayer to deliver a deed upon payment of the consideration as in Kyle. See Lucas v. North Texas Lumber Co., 281 U.S. 11 (1930) ; N. J. Arnold, 12 CCH Tax Ct. Mem. 280 (1953).

19. The most prevalent means of foreclosure of land mortgages is judicial sale, which requires a suit initiated by the mortgagee. See OSBORNE $\$ \S 10,317-36 ; 1$ GLENN $\$ 77$. An action at law on the obligation and execution on the security also necessitates suit by the mortgagee. See OsBorNE $\$ \S 314-16 ; 1$ GLENN $\$ 71$. Although the vendor may seek to avoid the need for judicial aid in foreclosure by including a power of sale in the security instrument, see OSBORNE $\$ \S 10,337-45$, or by attempting to exercise statutory self-help, see OsBorne $\$ \S 314-16 ; 1$ GLENN $\S 71$, or strict foreclosure, see OsBoRne $\$ \$ 311-13$; 1 GLENN $\$ \S 59.1,61,67$, judicial supervision is accessible to the mortgagor by a bill to redeem or for an accounting, see OSBORNE $\S 303 ; 1$ GreNN $\S 37.1$. And to obtain a deficiency decree, the creditor must bring suit against the debtor. See OsBonNe $\$ 333 ; 1$ Glen: $\$ \$ 77.2,101$.

20. Both a vendor who has retained title and a mortgagee must eject an unco-operative defaulting debtor to regain possession or sell. See 5 Tiffayy, Real Property $\$ 1412$ (3d ed. 1939). A vendor will then sue for damages to be made whole. See WaLsh $\$ 91$. Or, he may sue in equity to enforce his vendor's lien. See Annot., 91 A.L.R. 148, 151 (1934); WALSH $\$ 86$. See, generally, Osborne $\$ \$ 19,20 ; 1$ GLENN $\$ \$ 14-15.1$. Or he may sue to foreclose the vendee's equity. See 1 GLENN $\$ \S 15,67.1$; WALSH $\$ 91$. The vendor's remedies against a defaulting vendee will be determined by the underlying nature of the transaction rather than by its form. See, generally, OsBoRNE $\$ 20$; WaLSR $\S 91 ; 1$ GLENN $\S 67.1$. Therefore, retention of title by the vendor may be as insignificant to his rights against the defaulting vendee as the title or lien theory of mortgages is to the remedies of a mortgagee. See Sturges \& Clark, Legal Theory and Real Property Mortgages, 37 YALE L.J. 691 (1.928); note 21 infra.

Vendors may be induced to prefer the contract of sale by the possibility that it will be governed by freedom of contract doctrines rather than the traditional equitable principles applicable to mortgages. See OsBorne $\$ 20$. However, although the measure of damages in the action at law (contract minus market) theoretically is equivalent to the deficiency 
of the taxpayer in Kyle. ${ }^{21}$ Denying a bad debt deduction to one but not the other not only overlooks the equivalence of their performance and loss, it limits the seller's commercial alternatives. Unlike a mortgagee, the contract seller may avoid equity or right of redemption. ${ }^{22}$ Gearing a bad debt deduction for capital loss occasioned by the buyer's default to the passage or retention of title could force the seller to structure his transaction in a manner otherwise improvident.

The rationale underlying $K y l e$ 's denial of a bad debt deduction to an unsatisfied judgment creditor would further prejudice such a creditor if he subsequently recovered on the judgment. By treating the contract, default, sale on the market and uncollectible judgment as a single transaction on which a nondeductible loss was sustained, ${ }^{23}$ the court effectively prevented any subsequent recovery from qualifying as a return of capital. With the judgment deemed irrelevant to the tax consequences of the final sale, collection on the judgment could hardly be attributed to that sale. Since recovery would not be otherwise excludable, it would constitute ordinary income despite its fundamental character as a return of capital and gain on the sale of a capital asset. ${ }^{24}$ Again, un-

decree-downpayments and mortgage payments assumed equal--the jury at law constitutes an unpredictable variable in this determination. See, generally, GreEN, JudGe aNd JURY c. 15 (1930) ; Stalaraster, What Price Jury Trials? (1931) ; Elder, "Resolved That Jury Trials in Civil Cases Shourd Be Abolished" (Yale Law Library Pam. No. 5) (Debate over Radio WOR, New York City, Dec. 21, 1930).

21. See 1 Glenn $\$ \$ 30,36$; Osborne $\$ \S 129,133$; Tiffany, Real Property $\$ 873$ (abr. ed. 1940). The rights of the mortgagee as against the mortgagor supposedly depend upon whether the given jurisdiction adheres to a "title," "intermediate" or "lien" theory of mortgages. See OsBoRNE $\$ \$ 14,15,160,302$. However, the validity of a rigid theoretical or practical distinction between these theories is questionable. See OsBoRnE $\$ 16$; Sturges \& Clark, supra note 20; McDougal, Book Review, 44 Y ALE L.J. 1278 (1935).

22. Osbonne $\$ 20$. However, a seller surrendering possession while retaining title as security for the purchase money runs the risk of treatment as a mortgagee. See 1 GLENN $\$ 15.1$. Nevertheless, a preliminary sale contract, as distinguished from a long-term installment agreement, will give a vendor greater rights than a mortgagee, against both a vendee on default and third parties. See 1 GLENN $\$ 15$; OsBorne $\$ 20$. The agreement in $K y l c$, calling for complete payment of the purchase price in two weeks, was clearly a preliminary sale contract.

In some jurisdictions, a long-term contract vendor is allowed a right analogous to strict foreclosure. By so providing in the contract, he may escape a right to redeem in the vendee, keep the installments paid and sue for the installments due or damages. OSBORNE \$20. And, a vendor may structure a transaction to avoid the label "mortgage" and thus preclude risk of subordination to subsequent takers protected under recording acts. See Keefe v. Cropper, 196 Iowa 1179, 194 N.W. 305 (1923); OsBonne $\$ 213$.

23. 242 F.2d at 827 .

24. Recovery on a judgment constitutes income unless it is a return of capital or excludable under $\$ 104$ (a) (2) or $\$ 111$. Cf. INT. REv. CoDE of 1954, $\$ 61$ (a); 2 MERTENS \$12.40; Plumb, Income Tax on Gains and Losses in Litigation, 25 CORNeLL L.Q. 221 (1940). Subsequent recovery of the $K y l e$ debt could not consistently be treated as a return of capital, since the recovery in mitigation was postulated as the entire proceeds of a final sale upon which a nondeductible loss was computed. 242 F.2d at 827. INT. REv. CoDE or 1954, $\$ \$ 104$ (tort claims), 111 ( $\operatorname{tax}$ benefit rule), are inapplicable. However, the tax- 
like normal gain on the sale of a residence, that part of the judgment representing profit could not be applied to the basis of a new residence purchased by the taxpayer within one year. The Code permits such application only when the gain is derived from the sale of an old residence, ${ }^{25}$ and the reasoning that the judgment cannot constitute proceeds of the sale precludes satisfaction of this requirement.

The inequity of the refusal to allow a bad debt deduction in Kyle is demonstrated by extension of the court's reasoning to an accrual basis taxpayer who pays a tax on gain from the sale of a residence and fails to receive the gain. ${ }^{20}$ Normally, payment of a tax on income accrued but never received entitles a taxpayer to a deduction from current taxable income. ${ }^{27}$ Kyle denied a deduction when the taxpayer failed to realize a return of previously taxed capital..$^{29}$ Previously taxed capital is merely previously taxed income put to a capital use. ${ }^{29}$ Therefore, Kyle suggests that a deduction designed to compensate for failure to receive previously taxed income should also be denied. Further, if the accrual basis taxpayer were to sell his residence in mitigation, reduce his claim to judgment and recover, Kyle would dictate ordinary income taxation of the recovery. A tax equal to the difference between the capital gains tax paid and the income tax owing would be imposed even though the recovery over basis would in fact be capital gain. ${ }^{30}$

payer sought to deduct only the difference between his basis and the judgment and proceeds of the sale in mitigation, the extent to which he had failed to receive a return of capital. See notes 13,15 supra. Furthermore, tecovery constituting profit could not qualify as capital gain under the Kyle court's reasoning. Now, recovery of damages for breach of contract representing income which would have been received in prior taxable years is taxed at no greater rate than if received and taxed during those years under a new "spreadback" provision. INT. REv. CoDE of 1954, § 1305(a).

25. INT. REv. CoDE of 1954, $\S 1034$ (a), provides that gain on the sale of an "old (principal) residence" shall be recognized only to the extent that the taxpayer's adjusted sales price of the old residence exceeds his cost of purchasing a "new (principal) residence." Section 1034(e) dictates a commensurate reduction in the taxpayer's basis in the new residence.

26. See note 18 supra. See also Spring City Foundry Co. v. Commissioner, 292 U.S. 182 (1934) (accrual basis taxpayer required to report as income entire debt determined to be partially worthless in the taxable year, because he had right to receive the income during that year).

27. See Proposed U.S. Treas. Reg. $\$ 1.166-2$ (1956) (allowing deduction for nonrecovery of income items previously accrued) ; Spring City Foundry Co. v. Commissioner, supra note 26 (dictum allowing such a deduction). Because a variation in taxpayer's taxable income from year to year may result in different rates of taxation, a credit for overpayment would provide more accurate reimbursement than a deduction from current income. Cf. INT. REv. CODE of 1954, $\$ 1341$, allowing a taxpayer who restores income previously reported under an apparent claim of right either a deduction or a credit for tax paid, whichever is of greater benefit to him.

28. See note 24 supra.

29. See note 2 supra and accompanying text. Cf. French v. Wolf, 181 La. 733, 160 So. 396 (1935).

30. See INT. Rev. CoDe of 1954, $\$ 6211$. If an accrual basis taxpayer is not required to pay the difference between capital gains tax paid and ordinary income tax assessable, 
In addition to fostering inequitable tax treatment, rigid limitation of bad debt deductions to losses arising from unilaterally performed contracts frustrates the policy inherent in section $166 .^{31}$ The deduction compensates for taxes paid on capital lost to the taxpayer through another's promissory default. ${ }^{32}$ The requirement of promissory default insures nondeductibility of nonbusiness capital losses attributable to market fluctuations alone. ${ }^{33}$ Since it was realized on the market, the loss in Kyle may appear beyond the scope of section 166.34 However, the dominant cause of the loss was the promisor's breach. By inducing reliance on the contract, he became liable upon default for damages reflecting a drop in the market. ${ }^{35}$ Taxpayer's award of damages demonstrates that the source of the loss was the promisor's breach and not solely market fluctuation. For once a seller need no longer honor his contract, he will be required to sell to protect the promisor. Any judgment awarded but not recovered will be limited by the extent to which the seller's failure to mitigate prejudices the

he will be in a better tax position than a cash basis taxpayer, since $K y l e$ would require the latter to pay ordinary income tax on recovery over basis. But paying income tax is unjust in either case, for each only manifests a realization of capital gain. See note 12 sispra; note 24 supra and accompanying text.

31. One commentator who would so limit the deduction relies on alimony cases. 5 MERTENS $\$ 30.06$. But these cases do not manifest any failure to receive a return of capital. See note 3 supra.

32. See notes 1,2 supra and accompanying text.

33. See note 6 supra and accompanying text.

34. An oversimplified view of the facts is misleading. Taxpayer owned a house worth $\$ 16,500$ and sold it for $\$ 13,500$, thus sustaining a loss apparently caused by a drop in the market. Had taxpayer never regained possession of the house (for example, if it had been destroyed while in the vendee's possession) or had he kept it as his residence, the basic cause of the loss would have been evident. In either event, the contract vendee's obligation would not be submerged in a loss sustained and seemingly caused by a market drop. Instead, the judgment, representing the vendee's responsibility for the vendor's injury, would stand alone, nonrecovery exhibiting a bad debt loss.

If a taxpayer recovers neither possession of the house nor a complete return of capital, he should be allowed a bad debt deduction up to basis. The vendee would then be entitled to a casualty loss deduction if sudden accidental destruction were the reason for nonreturn. InT. Rev. Cone of 1954, $\$ 165$ (c) (3). If the taxpayer kept the house after regaining possession, he should be allowed to deduct nonrecovery up to basis as a bad debt but be required to make a commensurate reduction in basis for future tax purposes. If the house is lost by casualty after the taxpayer recovers possession, a casualty loss deduction up to market value and a bad debt deduction for the difference between market value and basis should be allowed.

35. 5 CORBIN $\$ \$ 992,1100,1145$, at 648,$652 ; 3$ CoRbIN $\$ \$ 662$, 666. The promisor is made to assume the risk of the market. See Fuller \& Perdue, The Reliance Interest in Contract Damages: 1, 46 Y YLE L.J. 52, 55, $74-75$ (1936) (expectation and reliance interests in contract damages may coalesce). The discussion in text assumes that the contract price was equal to fair market value when the contract was signed. If the contract price exceeded fair market value, the taxpayer's loss upon default might be attributed to prior market conditions. But contract law would still grant the vendor a judgment for the difference between contract and market price. 5 CorbIN $\$ \S 992,1002$; Restatement, ContRacts $\$ 329$ (1932). And recovery on the judgment would still constitute a return of 
buyer. ${ }^{36}$ Thus, although a taxpayer has not performed, if the market falls before the promisor's breach has created a duty to mitigate damages, any loss is necessarily caused by the promisor's breach and should, in so far as it represents unreturned capital, qualify as a bad debt. ${ }^{37}$ Occasioned by promissory default rather than market fluctuation, the loss manifests the very characteristics section 166 was designed to reach.

Permitting bad debt deductions for capital lost through breach of executory contracts will not increase tax avoidance opportunities. Admittedly, a taxpayer who must himself perform in order to acquire a bad debt deduction cannot structure a transaction to gain the deduction without incurring a concomitant loss. ${ }^{38}$ But since the debt must have a basis and be both valuable when acquired and subsequently proved worthless, ${ }^{39}$ evasion is also unlikely in the case of executory contracts. A taxpayer could not, for example, contract to sell his residence to a bankrupt accomplice, retain title and possession and later obtain a deduction; the debt would be worthless when acquired. ${ }^{40}$ Nor could he gain an undeserved deduction by selling to a solvent associate. Unless the promisor became insolvent, the debt could not be proved worthless. ${ }^{41}$ Thus unsupported

capital up to basis just as if the contract had been performed according to its terms. $C f$. 5 CoRBrN $\$ \$ 996$, at 14 (comparing restitution and damages), 1145 (price action and specific performance), 1221, 1222, 1224 (damages, restitution and specific performance). Consequently, failure to collect on the judgment should entitle the injured vendor to a bad debt deduction since he was unable to obtain a return of capital because of another's promissory default.

If the contract price were less than the taxpayer's basis in the property, the vendor would clearly be entitled to a bad debt deduction for nonrecovery up to contract price, and no more. Similarly, if the taxpayer contracted for less than fair market value, the judgment would again limit the bad debt deduction to the contract price. In neither case would the taxpayer be able to take a deduction beyond his basis.

36. Restatement, Contracts $\$ 336$ (1932); 5 Corbin $\S 1039$.

37. See note 35 supra.

38. See 5 Mertens $\$ 30.12$.

39. See INT. Rev. Code of 1954, § 166(b) ; note 1 supra.

40. In the case of a wholly executory contract, the debt may not appear to arise until the time of breach, when the injured party can obtain money damages. See 5 Corbin $\$ 995$, at 11 ; cf. Comment, 65 YAle L.J. 992 (1956); note 1 supra. And in many instances, a promisor is insolvent at the time of breach. Thus, the requirement that a debt have value when acquired, see note 1 sitpra, might seem to prevent a taxpayer injured by an insolvent's breach of an executory contract from obtaining a bad debt deduction. But when a court decrees compensatory money damages, it enforces a secondary obligation on the part of the promisor to save the promisee harmless in case of default. See 5 Corbin $\$ 995$; RestateMENT, CONTRACTS $\$ 329$ (1932). This obligation had value when acquired by the taxpayer upon contracting and became worthless upon the promisor's insolvency. Therefore, a deduction should be allowed for its worthlessness up to the taxpayer's basis.

Application of this rationale would continue to prevent deductibility of gifts disguised as loans, tax benefit from the voluntary acquisition of another's worthless debts or tax benefit from loans made without reasonable hope of repayment. See, generally, 5 MERTENS $\S 30.11$.

41. So long as the debt had value when acquired, awareness of a potential deduction for uncollectibility is not an element of a tax fraud. Moreover, a bad debt deduction re- 
by tax avoidance considerations, the case law restriction of section 166 to unilaterally performed contracts should be rejected in favor of a rule allowing bad debt deductions for all transactions which in fact encompass a failure, occasioned by promisory default, to realize a return of previously taxed capital.

quires a proportionate decrease in basis as the necessary result of the return of capital implied for tax purposes. See INT. REv. Cone of 1954, $\$ 1012,1016$; Ludlow Valve Mfg. Co. v. Durey, 57 F.2d 583 (N.D.N.Y. 1931), aff'd, 62 F.2d 508 (2d Cir. 1933). Accordingly, a taxpayer cannot gain a tax deduction and a subsequent tax-free return of capital by selling to a solvent buyer whom he expects to default. 